\title{
Consider What Passes for Kindness These Days
}

The farmers in 1942 Waterloo, Nebraska, would meet at the train tracks, their hands shoved deep and final in their overalls fingering lint, always lint.

My father would stand with his father whose withered arm hung limp at his side, his right hand in his pocket like the other complete, incomplete men, and wait with them

for the train to slow through town in a coughing arc where the men were waiting poised with their hands exhumed for the gathering of coal that the hoboes would throw,

scooping it out, handfuls of black hail, yawlping with beneficence, pleased with their work. The farmers would scurry about the tracks still ringing from the weight; they understood

each other's faces, the small acts that were beyond shame when one had warmth. My father would gather as his father would give a good-armed wave to the hoboes, shouting above the train whistle.

Call it another day of heat, with coal in pockets, everything chalky black. Hands at their sides, collars up, not quite slouching the warm walk home. 